\title{
EXAMINATION OF GONAD MATURITY AND FECUNDITY ASPECT OF TOMAN FISH (Channa micropeltus) DURING RAIN SEASON PERIOD IN RAWA DANAU PANGGANG WATERS, HULU SUNGAI UTARA DISTRICT, SOUTH KALIMANTAN.
}

\author{
Pahmi Ansyari*, Slamat \\ Fakultas Perikanan dan Kelautan Universitas Lambung Mangkurat \\ *p_ansyari@yahoo.com
}

\begin{abstract}
ABSTRAK
This study aims to find the level of gonad maturity and fecundity of toman fish living in the habitat of swamp waters Panggang Lake, Hulu Sungai Utara Regency, South Kalimantan during the rainy season period. Fish sampling were carried out every month for 3 months from January - March 2018. The method of determining the sampling location is used an analytical survey method (Analytic Survey Research Method). The results showed the gonad weight range of 11.77 to 0.18 grams and the level of gonad maturity varied from GML (gonad maturity level) I-IV, but dominated by GML I. The opportunity for fish populations to have mature gonads based on total length is $63.6 \%$ and gonad maturity index (GMI) between $0.05-0.73 \%$. Fecundity results obtained $29.67 \%$ and egg diameter of $1.57-2.05 \mathrm{~mm}$. This data shows that toman fish can spawn during the rainy season, but most of the population was maternity recovery state.
\end{abstract}

Keywords: gonada maturity, fecundity, toman fish, swamp waters.

\section{PENDAHULUAN}

Lahan basah yang terdapat di wilayah Kalimantan Selatan pada khususnya luasnya mencapai $\pm 1,4$ juta ha yang terdiri dari perairan sungai, danau, rawa, lebak dan payau (Mackinnon et al, 2001), sangat memungkinkan tumbuh dan berkembangnya berbagai jenis ikan seperti ikan toman (Channa micropeltes) yang merupakan spesies endemik perairan sungai dan danau. Ikan toman merupakan jenis ikan yang memiliki nilai ekonomis tinggi baik dilihat dari aspek ukuran, rasa dan harganya, sehingga upaya eksploitasi nelayan terus menerus dilakukan tanpa memperhatikan aspek kelestariannya. Permintaan pasar terhadap ikan toman terus meningkat, seperti pada tahun 2007 (5 ton/tahun) dan ditahun 2015 (> 9 ton/tahun), sementara produktivitasnya di alam terus menurun dari tahun 2007 (10 ton/tahun) dan ditahun $2012 \quad( \pm 3,7$ ton/tahun) (Diskanlaut, 2015). Upaya penelitian dan pengembangan ikan toman dirasa masih sangat terbatas sehingga referensinya sangat kurang.
Dalam rangka pengembangan budidaya ikan toman (Channa micropeltus) telah banyak dilakukan penelitian budidaya ikan tersebut, mulai dari pembenihan sampai dengan pembesaran. Hasil penelitian dari Fakultas Perikanan dan Kelautan ULM tentang domestikasi ikan toman telah menunjukkan hasil yang menggembirakan (Slamat dkk, 2014). Namun demikian untuk memproduksi benih ikan toman masih banyak kendala yang dihadapi. Pembenihan lebih banyak gagal, karena diduga belum kuatnya teoritis kajian tentang reproduksinya, sehingga belum banyak diketahui tentang biologi reproduksinya di alam yang dapat diterapkan secara manipulasi di perairan terbatas yang dapat dikendalikan. Dengan masalah ini, maka sangat urgen untuk melakukan penelitian tentang biologi reproduksi di habitat aslinya, terutama tentang kematangan gonada dan fekunditasnya. Diharapkan dari hasil penelitian ini didapatkan data dan kajian teoritis yang kokoh untuk biasa 
diaplikasikan pada kegiatan pembenihan ikan toman.

\section{METODE PENELITIAN}

Penelitian ini dilaksanakan di perairan umum rawa monoton Danau Panggang, Kecamatan Danau Panggang, Kabupaten Hulu Sungai Utara, Kalimantan Selatan untuk pengambilan sampel ikan. Sedangkan untuk analisa sampel ikan dilakukan di Laboratorium Biologi Perairan Fakultas Perikanan dan Kelautan Universitas Lambung Mangkurat. Waktu yang diperlukan dalam penelitian ini dilaksanakan kurang lebih 3 bulan dari bulan Januari s.d. Maret 2018. Metode penetapan lokasi digunakan metode survei analitis (Analytic Survey Research Method) yang refresentatif dengan ditetapkanya 3 (tiga) stasiun penelitian. Stasiun tersebut adalah daerah tangkapan (fishing ground) nelayan perairan rawa Danau Panggang, yaitu: Stasiun I $\left(115^{\circ} 01^{\prime} 27,13^{\prime \prime} \mathrm{BB} ; 2^{\circ}\right.$ $\left.22^{\prime}, 22,10^{\prime \prime}\right)$. Stasiun II (115 01'50,11" BB; $\left.2^{\circ} \quad 22^{\prime}, 16,17^{\prime \prime}\right)$ dan Stasiun III (115 $011^{\prime} 53,02^{\prime \prime} \quad$ BB; $\left.\quad 2^{\circ} \quad 22^{\prime}, 35,12^{\prime \prime}\right)$. Dilakukan survei dan pengambilan sampelsampel terhadap lokasi-lokasi yang stasiun yang representatif tersebut untuk memperoleh data primer. Selanjutnya pengambilan ikan contoh (sampling) dilakukan dalam periode 1 bulan sekali selama 3 bulan.

Sampel ikan yang diperoleh dari hasil tangkapan nelayan perairan umum di rawa Danau Panggang. Sebelum pengambilan gonada terlebih dahulu dilakukan pengukuran panjang total dan berat ikan. Selanjutnya dilakukan pembedahan di bagian ventral untuk mengeluarkan gonadanya, kemudian diberi kode, diawetkan dengan formalin dan disimpan dalam botol sampel. Kemudian dilakukan analisa di Laboratorium guna menganalisa tingkat kematangan gonada, fekunditas dan diamater telur. Untuk mendukung data utama, dilakukan pengambilan data sekunder berupa beberapa parameter kualitas air yang diambil pada lokasi yang sama dengan pengambilan contoh ikan.

Penentuan jenis kelamin dan perkembangan gonad dilihat secara makroskopis (melalui warna tubuh dan organ reproduksi) dan secara mikroskopis. Perkembangan gonad secara mikroskopis/histologis ditentukan dengan menggunakan modifikasi dari Syandri (1996) di dalam Effendie (2002). Penentuan Tingkat Kematangan Gonad (TKG) dapat dilihat pada perubahan struktur butir telurnya. Perubahanperubahan ini dibagi dalam 5 tingkat, yaitu: Tingkat I, II dan III dapat dibedakan pada perubahan gonadanya. Sedangkan perubahan tingkat IV dan $\mathrm{V}$ dapat dikenal dengan terbentuknya "yolk vesiole" dan "yolk globe" di dalam cytoplasma. Pada tingkat $\mathrm{V}$ dinding sel telur telah menebal dan nucleus telah bergeser ke tepi (Effendie, 2002).

Indeks Kematangan Gonad (IKG) dapat diketahui dengan cara mengukur berat gonad dan berat tubuh ikan tambakan. Gonad ditimbang dari masing-masing TKG. Nilai Indeks Kematangan Gonad (IKG) dianalisis dengan persamaan menurut Effendie (2002) yaitu persentase berat gonad terhadap berat tubuh ikan atau dengan persamaan:

$$
I K G=\frac{g}{W} x 100 \%
$$

di mana:

$$
\begin{array}{ll}
\mathrm{IKG} & =\text { Indeks Kematangan Gonad } \\
\mathrm{g} & =\text { berat gonad } \\
\mathrm{W} & =\text { berat tubuh ikan }
\end{array}
$$

\section{b. Fekunditas dan Diameter Telur}

Fekunditas yang dihitung ada dua macam, yaitu: (1) Fekunditas mutlak (butir) adalah jumlah telur betina masak sebelum dikeluarkan pada saat ikan memijah; Fekunditas relatif (\%) adalah jumlah telur per satuan berat ikan, dengan persamaan:

$$
F R=\frac{X}{W} x 100 \%
$$


di mana :

$$
\begin{aligned}
& \mathrm{FR}=\text { Fekunditas Relatif (\%) } \\
& \mathrm{X}=\text { Jumlah telur (butir) } \\
& \mathrm{W}=\text { Berat ikan (gram) }
\end{aligned}
$$

Fekunditas diasumsikan sebagai jumlah telur yang terdapat dalam ovari pada ikan dengan TKG IV. Telur diambil dari ikan betina dengan mengangkat seluruh gonadnya. Telur diawetkan dengan formalin $4 \%$, kemudian dihitung dengan metode gabungan (volumetric + gravimetric), dengan persamaan:

$$
\begin{aligned}
& F=\frac{G \cdot V \cdot X}{Q} \\
& \text { di mana: } \\
& \mathrm{F}=\text { Fekunditas / Jumlah telur total (butir) } \\
& \mathrm{G}=\text { Berat seluruh gonada (gram) } \\
& \mathrm{V}=\text { Volume pengenceran (cc) } \\
& \mathrm{X}=\text { Jumlah telur per cc (butir) } \\
& \mathrm{Q}=\text { Berat telur contoh (gram) }
\end{aligned}
$$

Diameter telur dapat diketahui dengan cara mengambil sebanyak masingmasing 10 butir dari ikan toman yang berada pada TKG IV dan V. Diameter telur diukur menggunakan mikroskop yang

\begin{tabular}{|c|c|c|c|c|c|c|c|c|c|}
\hline \multirow{3}{*}{ TKG } & \multicolumn{9}{|c|}{ Jenis Kelamin } \\
\hline & \multicolumn{2}{|c|}{ Januari } & \multicolumn{2}{|c|}{ Februari } & \multicolumn{2}{|c|}{ Maret } & \multicolumn{2}{|c|}{ Jumlah } & \multirow[t]{2}{*}{ Total } \\
\hline & Jantan & Betina & Jantan & Betina & Jantan & Betina & Jantan & Betina & \\
\hline I & 20 & 13 & 15 & 10 & 12 & 8 & 47 & 31 & 78 \\
\hline II & 7 & 6 & 12 & 5 & 6 & 5 & 25 & 16 & 41 \\
\hline III & 2 & 2 & 5 & 3 & 5 & 4 & 12 & 9 & 21 \\
\hline IV & 0 & 0 & 0 & 0 & 4 & 6 & 4 & 6 & 10 \\
\hline $\mathrm{V}$ & 0 & 0 & 0 & 0 & 0 & 0 & 0 & 0 & 0 \\
\hline Jumlah & 29 & 21 & 32 & 18 & 27 & 23 & 88 & 62 & 150 \\
\hline
\end{tabular}
dilengkapi dengan micrometer okuler.

\section{HASIL DAN PEMBAHASAN}

\section{Tingkat Kematangan Gonada (TKG)}

Berdasarkan pengamatan terhadap TKG ikan toman yang hidup di perairan rawa Danau Panggang disajikan pada Tabel 1 berikut ini:

Tabel 1. Hasil pengamatan terhadap TKG ikan toman selama tiga bulan (Januari, Februari dan Maret 2018) di rawa Danau Panggang

Tabel 1 menggambarkan bahwa ratio kelamin jantan dan betina ikan toman yang tertangkap setiap bulannya konsisten bahwa lebih banyak jantan dibanding betina. Secara keseluruhan selama 3 bulan ratio kelamin adalah 88 ekor jantan $(59 \%)$ dibanding 62 ekor betina $(41 \%)$. Hal ini berbeda dengan hasil yang diperoleh dari penelitian Sonnaria dkk (2015) di Danau Kelubi, Sanggau Kalimantan Barat, di mana komposisi populasi ikan toman jantan dan betina yang ditemukan bervariasi pada tiap bulan pengambilan sampel.

Hasil pengamatan TKG pada penelitian ini didapat bahwa pada bulan
Januari sampai Maret 2018 masih lebih banyak pada TKG I, tetapi seiring waktu TKG nya meningkat, di mana pada bulan Januari TKG I ikan jantan dan betina berjumlah 33 ekor (66\%), TKG II 13 ekor (26\%), TKG III (8\%), TKG IV dan TKG V tidak ada $(0 \%)$. Pada bulan Februari TKG I 25 ekor (50\%), TKG II 17 ekor (34\%), TKG III 8 ekor (16\%), TKG IV dan TKG $\mathrm{V}$ tidak ada (0\%). Selanjutnya pada bulan Maret TKG I 20 ekor (40\%), TKG II 11 ekor $(22 \%)$, TKG III 9 ekor (18\%), TKG IV 10 ekor (20\%) dan TKG V tidak ada $(0 \%)$. Berikut disajikan grafik komposisi TKG selama 3 bulan pengamatan (Gambar $1)$. 


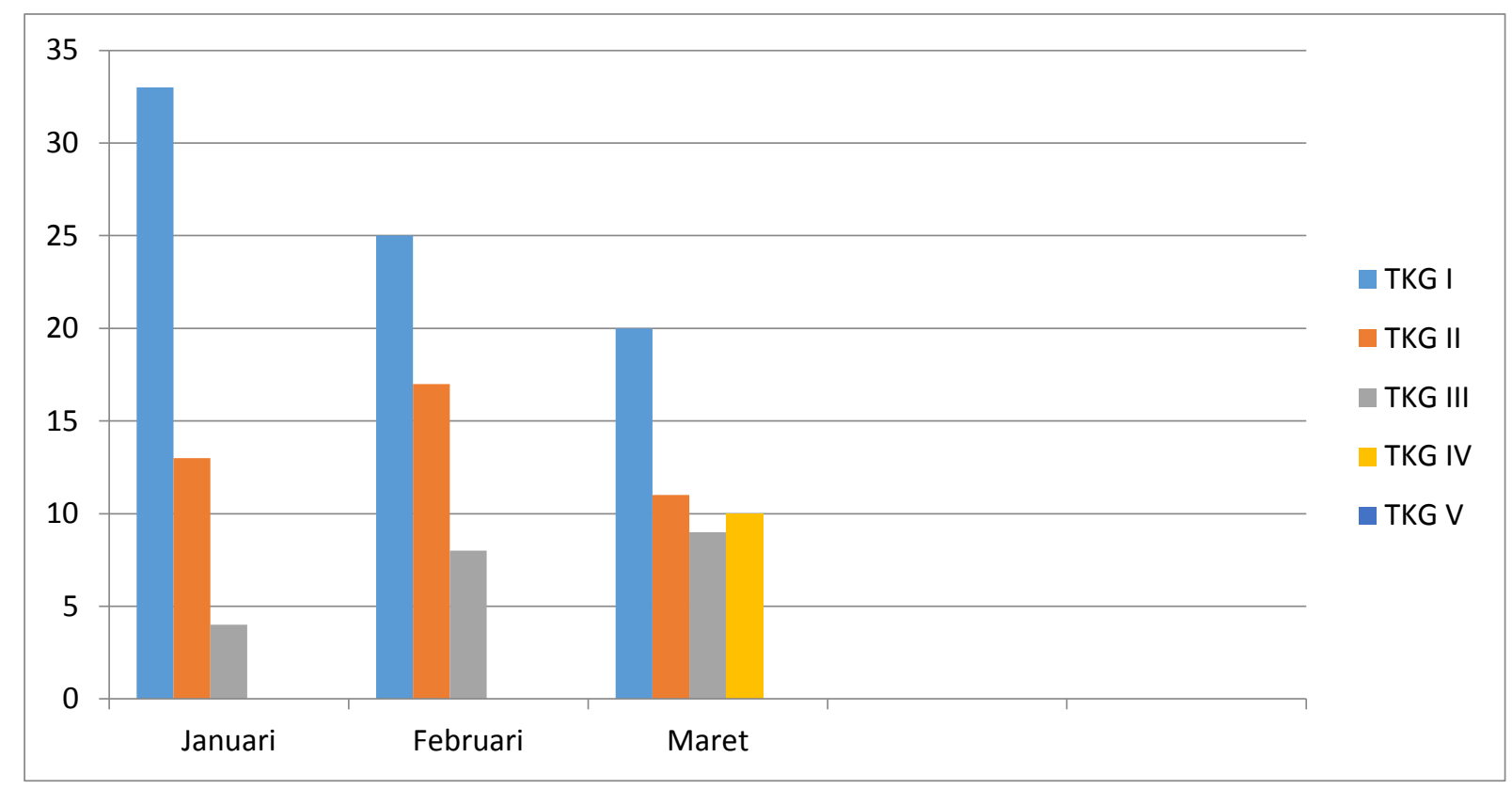

Gambar 1. Grafik komposisi TKG ikan toman selama pengamatan bulan Januari - Maret 2018

Hasil data di atas menggambarkan bahwa periode musim hujan TKG ikan toman di perairan rawa Danau Panggang didominasi oleh TKG I terutama pada bulan Januari dan pada bulan Februari TKG terus meningkat, di mana dominasi TKG I menurun dan TKG II dan TKG III meningkat. Bahkan pada bulan Maret sudah terdapat TKG IV dan TKG V. Fenomena ini menggambarkan bahwa pemijahan ikan toman di perairan rawa Danau Panggang dimulai akhir musim hujan (masa peralihan) dan puncaknya saat musim kemarau. Berarti diduga bahwa pematangan gonad dipengaruhi oleh sinyal alami seperti hujan, ketinggian air dan perubahan suhu lingkungan. Hal ini sesuai dengan pendapat Ramli $d k k$ (2010), bahwa mekanisme pematangan gonada ikan dipengaruhi sinyal lingkungan seperti hujan, perubahan suhu, substrat dan lainlain yang diterima oleh sistem syaraf pusat dan diteruskan ke hypothalamus. Namun demikian menurut hasil penelitian Makmur $d k k$ (2003) menunjukkan bahwa ikan gabus (Channa striata) satu famili dengan ikan toman bertelur sepanjang tahun.

\section{Indeks Kematangan Gonada (IKG)}

Hasil perhitungan IKG ikan toman di perairan rawa Danau Panggang disajikan pada Tabel 2 berikut ini:

Tabel 2. Indeks Kematangan Gonada (IKG) ikan toman di rawa Danau Panggang selama 3 bulan pengamatan

\begin{tabular}{|cccc|}
\hline Bulan & Jenis Kelamin & Jumlah ikan & Kisaran IKG (\%) \\
\hline \multirow{2}{*}{ Januari } & Jantan & 29 & $0,09-0,23$ \\
& Betina & 21 & $0,05-0,31$ \\
\cline { 2 - 4 } Februari & Jantan & 32 & $0,12-0,42$ \\
& Betina & 18 & $0,14-0,57$ \\
\cline { 2 - 4 } & Jantan & 27 & $0,19-0,66$ \\
\hline \multirow{2}{*}{ Maret } & Betina & 23 & $0,27-0,73$ \\
\cline { 2 - 4 } & & & \\
\hline
\end{tabular}

Berdasarkan Tabel 2 di atas, didapat data bahwa seiring dengan berakhirnya musim penghujan menuju ke arah musim transisi dan kemarau nilai IKG nya semakin besar yang berarti ikan toman semakin matang. Selanjutnya IKG ikan 
toman jenis kelamin jantan ternyata lebih cepat matang disbanding betina. Data yang lain nilai IKG pada periode musim hujan ini banyak terdapat di bawah $20 \%$. Menurut Bagenal dan Braum (1968) di dalam Efendie (2002), nilai IKG di bawah $20 \%$ menandakan bahwa ikan toman di perairan rawa Danau Panggang dapat memijah lebih dari sekali selama satu tahun. Selanjutnya dikatakan oleh Sonnaria $d k k$ (2015), IKG cenderung meningkat sejalan dengan perkembangan gonada ikan hingga mencapai nilai tertinggi pada saat matang gonad dan menurun kembali setelah ikan memijah.

\section{Fekunditas dan Diameter Telur}

Hasil perhitungan fekunditas dan pengukuran diameter telur ikan toman sampel yang hidup di perairan rawa Danau Panggang selama 3 bulan pengamatan disajikan pada Tabel 3 .

Tabel 3. Fekunditas dan diameter telur ikan toman di perairan rawa Danau Panggang selama 3 bulan pengamatan

\begin{tabular}{|cccccc|}
\hline $\begin{array}{c}\text { Bulan } \\
\text { Pengamatan }\end{array}$ & $\begin{array}{c}\text { Bobot ikan } \\
\text { sampel } \\
(\mathbf{k g})\end{array}$ & $\begin{array}{c}\text { Bobot Gonada } \\
\text { (gram) }\end{array}$ & $\begin{array}{c}\text { Kisaran } \\
\text { Fekunditas mutlak } \\
\text { (butir) }\end{array}$ & $\begin{array}{c}\text { Kisaran } \\
\text { Fekunditas Relatif } \\
(\mathbf{\%})\end{array}$ & $\begin{array}{c}\text { Diameter } \\
\text { Telur } \\
(\mathbf{m m})\end{array}$ \\
\hline Januari & $1,32-5,12$ & $0,18-2,52$ & $8.432-10.234$ & $5,24-12,30$ & $1,57-1,73$ \\
\hline Februari & $1,51-5,27$ & $1,19-9,30$ & $15.234-17.329$ & $7,79-25,73$ & $1,79-1,87$ \\
\hline Maret & $1,62-5,32$ & $3,14-11,77$ & $17.674-20.327$ & $8,10-29,67$ & $1,85-2,05$ \\
\hline
\end{tabular}

Fekunditas dan diameter telur berkaitan erat (korelasi) dengan jumlah telur. Dibanding penelitian Sonnaria $d k k$ (2015), diperoleh fekunditas ikan toman sebanyak 14.056 butir/individu dengan bobot tubuh 2.501 gram dan bobot gonada 12,32 gram. Diameter telur berkisar antara 2,30 - 2,57 $\mathrm{mm}$ yang dilaksanakan di danau Kelubi, Kabupaten Sanggap pada Desember 2013, maka kematangan gonada lebioh dahulu dibanding hasil yang diperoleh di perairan rawa Danau Panggang. Menurut Said (2007), diameter ikan serandang (Channa pleuropthalamus) (satu famili dengan ikan toman) berkisar antara 0,2 - 0,48 $\mathrm{mm}$. Ukuran diameter telur yang didapat dari sampel menyebar secara nyata. Hal ini menggambarkan ikan toman di perairan rawa Danau Panggang kemungkinan melakukan pemijahan secara parsial. Artinya pemijahan terjadi karena telur yang matang yang masih berada di dalam tubuh ikan betina dikeluarkan waktu pemijahan, sedangkan yang belum matang dikeluarkan pada pemijahan berikutnya. Kondisi ini diperoleh dari kondisi teluar yang tidak matang bersamaan. Menurut Sonnaria $d k k$ (2015), ikan yang melakukan pemijahan secara parsial memiliki waktu pemijahan yang panjang. Hasil penelitian ini diperkuat oleh penelitian Makmur (2006) bahwa ikan gabus (Channa striatus) berpijah sepanjang tahun (ikan gabus satu famili dengan ikan toman, yaitu famili Channnidae).

\section{Kualitas Perairan}

Kualitas perairan rawa Danau Panggang tentunya dipengaruhi oleh faktor fisika, kimia dan biologi perairan. Berikut ini disajikan hasil pengukuran beberapa parameter kualitas air secara in situ maupun yang dianalisa di laboratorium pada Tabel 5. 
Tabel 5. Hasil pengukuran beberapa parameter kualitas air di perairan rawa Danau Panggang habitat ikan toman

\begin{tabular}{|cccccc|}
\hline \multirow{2}{*}{$\begin{array}{c}\text { Bulan } \\
\text { Pengamatan }\end{array}$} & $\begin{array}{c}\text { Suhu air } \\
\left({ }^{0} \mathrm{C}\right)\end{array}$ & $\begin{array}{c}\text { Oksigen terlarut } \\
(\mathrm{ppm})\end{array}$ & pH air & $\begin{array}{c}\text { Ammoniak } \\
(\mathrm{ppm})\end{array}$ & $\begin{array}{c}\text { Kecerahan } \\
(\mathrm{cm})\end{array}$ \\
\hline Januari & $26-28$ & $5,9-6,0$ & $5,74-6,90$ & $0,01-0,02$ & $1,8-2,1$ \\
\hline Februari & $26-29$ & $5,5-5,9$ & $5,78-6,85$ & $0,01-0,03$ & $1,7-2,0$ \\
\hline Maret & $26-29$ & $5,7-6,1$ & $5,66-6,83$ & $0,01-0,03$ & $1,7-1,9$ \\
\hline
\end{tabular}

Hasil beberapa parameter kualitas air (suhu, oksigen terlarut, $\mathrm{pH}$ air, ammoniak dan kecerahan) pada habitat ikan toman di perairan rawa Danau Panggang seperti di atas, masih dalam keadaan normal dan relatif tidak terlalu berubah siginifikan antara bulan Januari sampai dengan Maret 2018. Hal ini memberikan kondisi yang sesuai dengan pertumbuhan dan perkembangan ikan toman di perairan tersebut. Menurut Bijaksana (2015), untuk merangsang ikan untuk berkembang gonadanya diperlukan kualitas air yang prima, terutama rangsangan fluktuasi kedalaman air ataupun juga kecerahan air. Selanjutnya menurut Ansyari dan Rifa'i (2009), perairan rawa kualitas airnya sangat prima pada musim hujan, sehingga memberikan kondisi yang terbaik bagi pertumbuhan dan perkembangan biota yang ada di perairan tersebut.

\section{KESIMPULAN}

Berdasarkan hasil penelitian di atas dapat ditarik kesimpulan bahwa ikan toman dapat memijah sepanjang tahun dengan frekuensi lebih dari satu kali dalam satu tahun. Pemijahan dapat berlangsung musim hujan, terus meningkat pada musim peralihan dan diduga puncaknya pada musim kemarau. Pemijahan dipengaruhi oleh kondisi perairan, terutama parameter kunci kualitas air seperti suhu perairan, $\mathrm{pH}$ air, oksigen terlarut, ammoniak-nitrogen dan fluktuasi kedalaman air.

\section{UCAPAN TERIMA KASIH}

Terima kasih disampaikan kepada Bapak Prof. Dr. Ir. M. Arief Soendjoto, M.Sc selaku Ketua Lembaga Penelitian dan Pengabdian kepada Masyarakat dan Ibu Dr. Ir. Fatmawati, M.Si selaku Ketua Program Studi Budidaya Perairan serta teman-teman sejawat dan para mahasiswa Fakultas Perikanan dan Kelautan Universitas Lambung Mangkurat yang telah banyak membantu secara moril dan bantuan di lapangan, sehingga penelitian ini dapat terlaksana sesuai dengan yang direncanakan.

\section{DAFTAR PUSTAKA}

1. Anonimous. 2015. Laporan Tahunan Dinas Kelautan dan Perikanan Provinsi Kalimantan Selatan.

2. Ansyari, P dan M.A. Rifai. 2009. Kualitas Air di Perairan Rawa Kalimantan Selatan. Laporan Penelitian Fakultas Perikanan Unlam Banjarbaru.

3. Bijaksana, U. 2015. Fisiologi Hewan Air. P3AI Universitas Lambung Mangkurat Banjarbaru. 188 halaman

4. Effendie, M.I. 2002. Biologi Perikanan. Yayasan Pustaka Nusatama. Yogyakarta. 135 halaman.

5. Mackinoon, E. Mangalik, A. Chariuddin dan Hatta, G. 2001. Ekologi Kalimantan. Universitas Lambung Mangkurat. 303 halaman. 
6. Makmur, S dan Prasetyo, D. 2006. Kebiasaan Makan, Tingkat Kematangan Gonada dan Fekunditas Ikan Haruan (Channa striata Bloch) di Suaka Perikanan Sungai Sambujur DAS Barito Kalimantan Selatan. Jurnal Ilmu-Ilmu Perairan dan Perikanan Indonesia, Juni 2006, Jilid 13, Nomor 1: 27

7. Ramli, R, Bijaksana, U. dan Balantek. 2010. Kajian Status Reproduksi Dan Penanganan Larvalkan Gabus,Channa Striata Blkr Sebagai Dasar ManipulasiUntuk Domestikasi Komoditas Rawa. Program Penguatan PS. Budidaya Perairan I-MHERE B.1 Unlam.

8. Said, A. 2007. Beberapa Jenis Kelompok Gabus (Marga Channa) di Daerah Aliran Sungai Musi, Sumatera Selatan. Jurnal Bawal. Vol 1 No.4 April 2007: 121 - 126.

9. Slamat. 2014. Domestika Ikan Toman. Fakultas Perikanan dan Kelautan Universitas Lambung Mangkurat.

10. Sonnaria, N.A; Yanti, A.H dan Setyawati, T.R. 2015. Aspek Reproduksi Ikan toman (Channa micropelter Cuvier) di danau Kelubi Kecamatan Tayan Hilir Kabupaten Sanggau. Jurnal Protobiont (2015). Vol. 4 (1): 38 - 45. 